\title{
Effect of 2,4-D on Growth, Yield and Quality of Wax Apple (Syzygium samarangense, (Blume) Merrill \& L.M. Perry cv. Jambu Madu) Fruits
}

(Kesan 2,4-D ke atas Pertumbuhan, Hasil dan Kualiti Buah Syzygium samarangense,

(Blume) Merrill \& L.M. Perry cv. Jambu Madu)

\author{
MOHAMmad MONERUZZAman KHANDAKER*, NORMANIZA OSMAn, ABM SHARIF Hossain, \\ GOLAM FARUQ \& AMRU NASRULHAQ BOYCE
}

\begin{abstract}
In this study, we investigated the effects of 2,4-Dichlorophenoxy acetic acid (2,4-D) treatment on selected physiological parameters and fruit quality of wax apple fruits under field conditions. Foliar spray of 2,4-D at 0, 5, 10 and 20 mg $L^{-1}$ concentrations were used from bud stage to the 3rd week of fruit development. Physiological parameters determined included net photosynthesis, stomatal conductivity, chlorophyll content and chlorophyll fluorescence. Net photosynthetic rate and photosynthetic efficiency via chlorophyll fluorescence significantly (p $\leq 0.05)$ increased with 5 and $10 \mathrm{mg} \mathrm{L}^{-1} 2$, 4-D treatments. Furthermore, $5 \mathrm{mg} \mathrm{L}^{-1}$ 2,4-D reduced bud and fruit drop, increased fruit weight and dry matter content in leaves. An improved fruit set, enhanced fruit growth, faster color development and advanced maturity were also recorded in treated plants. In addition, fruit yield increased by 39 and $48 \%$ with 5 and $10 \mathrm{mg} \mathrm{L}^{-1}$ 2,4-D treatments, respectively. Fruit $K^{+}$content, total sugar, protein content and chalcone synthase (CHS) activities increased with 2,4-D treatments. Increased leaf soluble protein and elevated sucrose phosphate synthase (SPS) activity were also observed in $5 \mathrm{mg} L^{-1}$ treated plants. Positive correlation between photosynthesis rate and SPS activity of leaves $\left(R^{2}=0.98\right)$ and between CHS activity and color development of fruits $\left(R^{2}=0.98\right)$ were recorded in $5 \mathrm{mg} L^{-1}$ treatments. The results also suggested that 5 and $10 \mathrm{mg} \mathrm{L}^{-1} 2,4-D$ treatments are promising for enhancing plant productivity and fruit quality in wax apple trees under field conditions.
\end{abstract}

Keywords: Development; fruit; quality; yield; wax apple; 2,4-D

ABSTRAK

Dalam penyelidikan ini, kami mengkaji kesan aplikasi 2,4-Dichlorophenoxy asid asetik (2,4-D) pada parameter fisiologi yang dipilih dan kualiti buah jambu madu di bawah keadaan ladang. Semburan foliar 2,4-D dengan kepekatan 0, 5, 10 dan 20 mg L-1 digunakan pada peringkat putik hingga ke minggu ke-3 pembentukan buah. Parameter fisiologi yang ditentukan termasuk fotosintesis bersih, kekonduksian stomata, kandungan klorofil dan klorofil pendarfluor. Kadar fotosintesis bersih dan kecekapan fotosintesis melalui klorofil pendarfluor meningkat dengan ketara $(\mathrm{p} \leq 0.05)$ dengan rawatan 5 dan 10 mg L-1 2,4-D. Tambahan pula, rawatan 5 mg L-1 2,4-D mengurangkan keluruhan putik dan buah dan meningkatkan berat buah dan kandungan bahan kering dalam daun. Set buah yang ditambah baik, pertumbuhan yang dipertingkatkan, pembangunan warna yang lebih cepat dan kematangan yang maju juga dicatatkan bagi tumbuhan yang dirawat. Di samping itu, penghasilan buah telah meningkat sebanyak 39 dan $48 \%$ dengan rawatan masing-masing 5 dan 10 mg L-1 2,4- D. Kandungan $K^{+}$, jumlah gula, kandungan protein dan aktiviti kalkon sintase (CHS) dalam buah meningkat dengan rawatan 2,4-D. Peningkatan protein larut daun dan aktiviti sukrosa fosfat sintase (SPS) juga diperhatikan dalam $5 \mathrm{mg}$ L-1 tumbuhan yang dirawat. Hubungan positif antara kadar fotosintesis dan aktiviti SPS daun $(R 2=0.96)$ serta antara aktiviti CHS dan pembangunan warna buah $(R 2=0.98)$ dicatatkan dalam rawatan 5 mg L-1. Keputusan menunjukkan bahawa rawatan 5 dan $10 \mathrm{mg}$ L-1 2,4- D menjanjikan keadaan peningkatan produktiviti tanaman dan kualiti buah dalam jambu madu dalam ladang.

Kata kunci: Buah; hasil; jambu madu; kualiti; pertumbuhan; 2,4-D

\section{INTRODUCTION}

Wax apple (Syzygium samarangense) is a non-climacteric tropical fruit from the Myrtaceae family originating from Malaysia and other South-East Asian countries (Morton 1987). In the last few decades, wax apple trees were often cultivated in homestead areas with limited commercial production in Malaysia, Thailand, Indonesia, Philippines, Taiwan as well as other South and South East Asian countries (Janick \& Paul 2008). Presently, wax apple is widely cultivated throughout Indonesia, Thailand, Taiwan and Malaysia with a total area of 32496 ha in 2003-2005 (Zen-hong et al.2006). The pear shaped fruits, are usually 
in red, pink or greenish in colour, with a dense body, crispy, sweet to taste and has a pleasant aromatic flavour. Because of its excellent quality, the fruits have become one of the most sought-after and competitive fruits in Asian countries. Wax apple fruits are eaten fresh and in jams, jellies, desserts, wines, liquors and vinegars. The fruits has been used for sore throat, high blood pressure and ringworm as well as an antimicrobial, antiscorbutic, carminative, diuretic and astringent (Rivera \& Obón 1995). The Malaysian tropical climate is suitable for the cultivation of wax apple throughout the year and as a result the fruits have become one of the country's most valuable fruit crops.

In Malaysia as well as other tropical countries, wax apple growers encounter several problems with regard to wax apple production. Severe bud and fruit drop, small fruit, less ripening colour and low quality impair production as well as consumer's preference, resulting in lower market price. Plant growth regulators have been used extensively in fruit research and fruit quality improvement over the years. Synthetic auxin $(2,4-D)$ has been used to reduce fruit drop, enhancing fruit growth and yield and improving quality (Sterling \& Hall 1997). Recently, it has been reported that 2,4-D treatment retarded fruit senescence by altering the levels of many endogenous hormones and by improving stress defence capabilities by up-regulating defence-related genes and proteins (Ma et al. 2014). Auxins can substitute for pollination and induce fruit set and growth, development as well as quality (Kataoka et al. 2009). It has been reported that 2,4-D significantly improves fruit size, yield, colour, total soluble solids (TSS), total sugar content and enhances the activities of antioxidant enzymes in Bing Cherry fruits (Baogang et al. 2008; Raphael et al. 2007). Tuan et al. (2013) reported that, spraying $\mathrm{GA}_{3}$ and 2,4-D increased the fruit set, fruit growth as well as improving the fruit quality of wax apple. 2,4-D has been shown to significantly increase fruit weight, number of fruits, juice percentage, total soluble solids (TSSs), ascorbic acid content, acidity and TSS/acid ratio and reduced the fruit drop of Kinnow (Citrus reticulata Blanco) fruit (Ashraf et al. 2013). Moreover, 2,4-D treatment increases chlorophyll synthesis and net photosynthesis rate in fresh water green algae (Wong 2000). We have also reported that glucose, fructose, vitamin-C, phenol, flavonoid and antioxidant capacity of wax apple fruits are increased by 2,4-D treatments (Khandaker et al. 2012a). Pulp firmness, fruit juice and fruit pigmentation of wax apple have also been observed to increase with 2,4-D treatment.

This paper presents data on the influence of 2,4-D on the physiological activities of wax apple. In the three years of study, we investigated the effects of 2,4-D on several photosynthetic characteristics, sucrose phosphate synthase activity, fruit growth, yield and quality under field conditions. It is proposed that the application of 2,4-D can affect or promote the growth, development and quality of the wax apple fruit.

\section{MATERIALS AND METHODS}

\section{EXPERIMENTAL DETAILS}

Two different orchards located at MARDI, Klang and a farm in Banting, $2^{0} 30 \mathrm{~N}, 112^{\circ} 30 \mathrm{E}$ and $1^{\circ} 28 \mathrm{~N}, 111^{\circ} 20 \mathrm{E}$ were used for the conduction of three years studies. The experimental areas were in a tropical climate and $45 \mathrm{~m}$ above sea level. The soil of Klang and Banting orchard was slightly acidic (pH4.6) (Ismail et al. 1995). We applied 1 bag $(15 \mathrm{~kg})$ of sawdust compost and decomposed cow dung per tree for acidity neutralization. All of the three years experiments were carried out from 2008- 2011.

\section{PLANT MATERIALS AND TREATMENT APPLICATION}

Wax apple trees at about 12 years old were used in this study. All of the selected trees received the same agronomical and horticultural management practices. Twenty trees were used in the experiment for each year. In this study, a total of one hundred branches (five branches per tree) were used from the twenty trees. The selected uniformed branches were sprayed with 5, 10 and $20 \mathrm{mg} \mathrm{L}^{-1}$ 2,4-D and water (control) at one week interval with total of four times; one time at bud stage and three times after anthesis. A volume of $300 \mathrm{~mL}$ 2,4-D solution was used per treatment (twenty five branches). After 4th spray, all the treated and control fruits were wrapped with polythene bags. The experiments were arranged in a Randomized Complete Block Design (RCBD).

\section{MEASUREMENT OF PHYSIOLOGICAL AND BIOCHEMICAL PARAMETERS}

The total number of buds, fruit set, growth (length and diameter), drop, weight and yield were measured according to Khandaker et al. (2012b). Leaf dry matter was measured at $0 \%$ moisture. Chlorophyll meter (SPAD502) was used for the measurement of the chlorophyll content of wax apple leaves during the fruit development. Chlorophyll fluorescence and quantum yield were measured by Hansatech Plant Efficiency Analyzer (PEA) and measurements were carried out according to methods of Khandaker et al. (2011). Stomatal conductance was measured by a Leaf Porometer in a sunny day (800- 1500 $\mu \mathrm{E} \mathrm{m}^{-1} \mathrm{~s}^{-1}$ ) during the $3 \mathrm{rd}$ week of fruit development period. The surface colour of each tagged fruit was measured using a Minolta colorimeter (CR-300, Konica, Japan). Parameters such as 'L' (lightness), ' $a$ ' (greenness to redness) and ' $b$ ' (blueness to yellowness) were determined at distal and proximal end and middle portion of the sample fruits. Peel colour was expressed in $\mathrm{L}^{*}, \mathrm{a}^{*}, \mathrm{~b}^{*}$ Hunter parameter, using the following formula $\left(L^{*} \times a^{*}\right) / b^{*}$.

Fruit juice $\mathrm{K}^{+}$content was evaluated with a Cardy Potassium meter (Horiba C-131, Japan). Phenolsulphuric method of Dubois et al. (1956) was used for the determination of total sugar content of wax apple fruits. The activity and level of chalcone synthase enzyme was determined according to the methods described by Edwards 
et al. (1990). The photosynthetic rate $(P n)$ was measured using a portable photosynthesis system (Li-6400XT, LiCOR, USA) and measurements were carried out according to methods of Khandaker et al. (2012b). The Bradford method was used for the determination of the leaf and fruit protein content of wax apple (Bradford 1976). Sucrose phosphate synthase activity was assayed under Vmax condition according to the methods of Hubbard et al. (1989).

\section{STATISTICAL ANALYSIS}

Randomized Complete Block (RCB) design with five replications was used in all experiments. The pooled data were analyzed using MSTAT-C statistical software. One way ANOVA was used to calculate the significant the treatments and control. Least significant difference (LSD) and honestly significant difference (HSD) were used to justify significant F-test $(p=0.05)$.

\section{RESULTS}

\section{FLOWER BUD DEVELOPMENT, FRUIT SET,} GROWTH AND DEVELOPMENT

As shown in Table 1, there was no difference in flower bud number between the treatments and control. On the other hand, 2,4-D treatment produced a noticeable difference on bud drop in the wax apple fruits (Table 1). The highest bud drop (45\%) was recorded in the $20 \mathrm{mg} \mathrm{L}^{-1} 2,4-\mathrm{D}$ treatment, whilst the least (32\%) bud drop observed in $5 \mathrm{mg} \mathrm{L}^{-1}$ treated branches. With regard to fruit set, it was found significantly higher in treatments compared with control. Fruit growth rate throughout the fruit developmental period in treated branches were significantly higher than the control branches (Figure 1).

During the 3rd week of inspection, fruit length was 3.4 and $3.2 \mathrm{~cm}$ in 10 and $5 \mathrm{mg} \mathrm{L}^{-1} 2,4-\mathrm{D}$ treatments, respectively, whereas, fruit length was $2.6 \mathrm{~cm}$ in the control (Figure 1(a)). At the same time, fruit diameters, were 2.63 and $2.43 \mathrm{~cm}$ in 10 and $5 \mathrm{mg} \mathrm{L}^{-1} 2$, 4-D treated fruits, respectively, whereas fruit diameter was $2.13 \mathrm{~cm}$ in control fruits (Figure 1(b)).

This increased growth trend was recorded until fruit maturation. Treated fruits grew at a significantly higher rate and this stimulating effects was observed until fruit maturation.

\section{FRUIT DROP AND AVERAGE FRUIT WEIGHT}

The application of 2,4-D treatment produced a significant effect on fruit drop in wax apple fruits (Table 1). The results showed that untreated branches showed the highest fruit drop (41\%) followed by 10 and $20 \mathrm{mg} \mathrm{L}^{-1} 2,4-\mathrm{D}$ treatment with a fruit drop of 26 and $25 \%$, respectively, whereas, $5 \mathrm{mg} \mathrm{L}^{-1}$ treated branches showed the least percentage of fruit drop (18\%). The application of 2, 4-D treatment also significantly increased the fruit weight as compared with control. As can be seen from Table 1, the average fruit weight was the highest (46 g) in $5 \mathrm{mg} \mathrm{L}^{-1} 2,4-\mathrm{D}$ treated branches followed by the 10 and $20 \mathrm{mg} \mathrm{L}^{-1} 2,4-\mathrm{D}$ treatments, whilst, the control treatment produced the lowest fruit weight $(32 \mathrm{~g})$.

\section{LEAF DRY MATTER AND CHLOROPHYLL CONTENT OF LEAF}

Leaf dry matter content in the treated branches were significantly higher than the control treatment (Table 1).

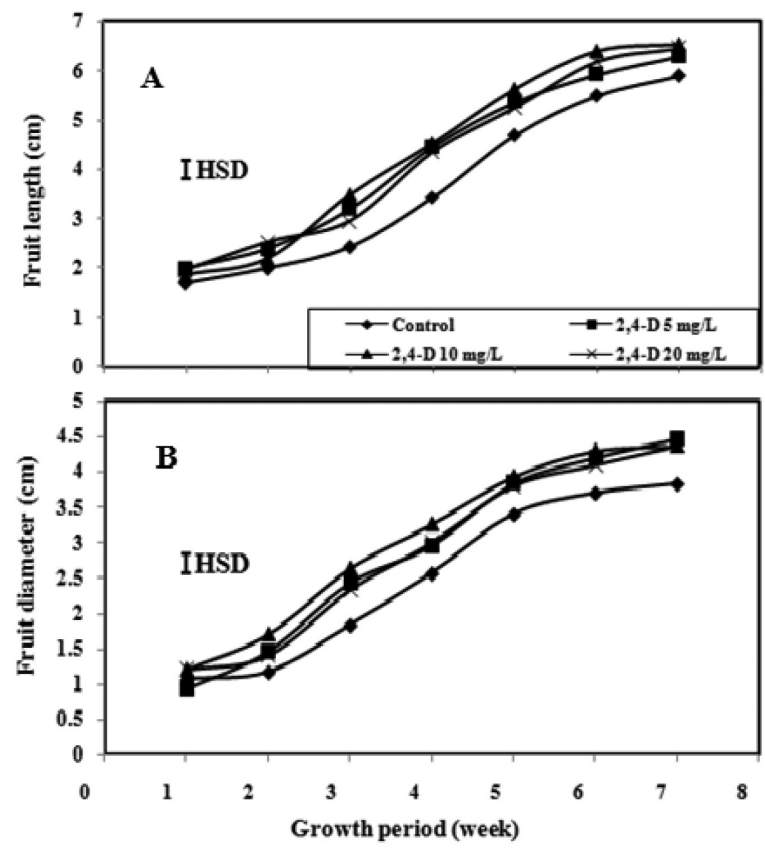

FIGURE 1. Fruit growth (cm) length (a) and diameter (b) of wax apple as influenced by different treatments of 2,4-D under field conditions $(n=12)$. Vertical bars indicate HSD value at $5 \%$ level of significance

TABLE 1. Effects of different treatments of 2,4-D on number of buds, bud drop, fruit set, fruit drop, fruit weight, dry matter and chlorophyll content of wax apple

\begin{tabular}{cccccccc}
\hline $\begin{array}{c}\text { Treatment } \\
\left(\mathrm{mg} \mathrm{L}^{-1}\right)\end{array}$ & $\begin{array}{c}\text { Bud } \\
\text { number }\end{array}$ & $\begin{array}{c}\text { Bud drop } \\
(\%)\end{array}$ & $\begin{array}{c}\text { Fruit set } \\
(\%)\end{array}$ & $\begin{array}{c}\text { Fruit drop } \\
(\%)\end{array}$ & $\begin{array}{c}\text { Av. fruit } \\
\text { wt. }(\mathrm{g})\end{array}$ & $\begin{array}{c}\text { DM } \\
\left(\mathrm{g} \mathrm{leaf}^{-1}\right)\end{array}$ & $\begin{array}{c}\text { Chlorophyll } \\
(\text { SPAD })\end{array}$ \\
\hline Control & $49 \pm 5.7 \mathrm{a}$ & $35 \pm 3.6 \mathrm{~b}$ & $18 \pm 1.3 \mathrm{~b}$ & $41 \pm 6.0 \mathrm{a}$ & $32 \pm 2.0 \mathrm{c}$ & $1.12 \pm 0.1 \mathrm{~b}$ & $54 \pm 3.0 \mathrm{c}$ \\
2,4-D 5 & $53 \pm 2.3 \mathrm{a}$ & $32 \pm 1.8 \mathrm{~b}$ & $27 \pm 4.4 \mathrm{a}$ & $18 \pm 4.9 \mathrm{c}$ & $46 \pm 2.8 \mathrm{a}$ & $1.44 \pm 0.2 \mathrm{a}$ & $71 \pm 2.4 \mathrm{a}$ \\
2,4-D 10 & $56 \pm 3.5 \mathrm{a}$ & $43 \pm 3.0 \mathrm{a}$ & $31 \pm 4.7 \mathrm{a}$ & $26 \pm 4.9 \mathrm{~b}$ & $42 \pm 2.6 \mathrm{a}$ & $1.66 \pm 0.1 \mathrm{a}$ & $70 \pm 2.5 \mathrm{a}$ \\
2,4-D 20 & $52 \pm 4.0 \mathrm{a}$ & $45 \pm 2.3 \mathrm{a}$ & $29 \pm 2.7 \mathrm{a}$ & $25 \pm 5.0 \mathrm{~b}$ & $38 \pm 1.8 \mathrm{~b}$ & $1.41 \pm 0.1 \mathrm{a}$ & $62 \pm 3.0 \mathrm{~b}$ \\
\hline
\end{tabular}

Values in a column sharing the same lower case letters are not significantly different at $p \leq 0.05$ (LSD test) 
The highest leaf dry matter (1.66 g) was recorded in the $10 \mathrm{mg} \mathrm{L}^{-1} 2,4-\mathrm{D}$ treated branches, whereas the control treatment produced the least amount of dry matter $(1.12 \mathrm{~g})$.

Leaf chlorophyll content is another important factor that reflects plant health and productivity. The chlorophyll readings (SPAD) in leaves from all the 2,4-D treatments were significantly higher compared with untreated leaves and they were 1.31 fold higher in $5 \mathrm{mg} \mathrm{L}^{-1} 2,4-\mathrm{D}$ treated branch branches (Table 1).

\section{CHLOROPHYLL FLUORESCENCE AND STOMATAL CONDUCTANCE}

Leaf chlorophyll fluorescence was significantly affected by 2,4-D treatments (Table 2). Leaves of $5 \mathrm{mg} \mathrm{L}^{-1}$ treated branch yielded the highest maximum fluorescence $\left(\mathrm{F}_{\mathrm{m}}\right)$, whilst, the lowest $\mathrm{F}_{\mathrm{m}}$ value was recorded in the control treatment. The highest ground state fluorescence $\left(\mathrm{F}_{0}\right)$ was also observed in the $5 \mathrm{mg} \mathrm{L}^{-1}$ treatment. Treatment with 2,4-D at $5 \mathrm{mg} \mathrm{L}^{-1}$ treatment produced the highest relative variable fluorescence $\left(\mathrm{F}_{\mathrm{v}}\right)$, whereas, control leaves exhibited least fluorescence (Table 2). Foliar application of 2,4-D produced a significant effect on photosynthetic optimum quantum yield. The highest optimum quantum yield $\left(\mathrm{F}_{\mathrm{v}} / \mathrm{F}_{\mathrm{m}}\right)(0.83)$ was recorded in $5 \mathrm{mg} \mathrm{L}^{-1} 2,4-\mathrm{D}$ treated leaves, whilst the control showed the least quantum yield (0.71) (Table 2). Leaf stomatal conductivity of wax plant was significantly affected by 2,4-D treatments (Table 2). The results showed that the highest stomatal conductivity $\left(0.04 \mathrm{~mol} \mathrm{H}_{2} \mathrm{O} \mathrm{m}^{-2} \mathrm{~s}^{-1}\right)$ was observed in $5 \mathrm{mg} \mathrm{L}^{-1} 2,4-\mathrm{D}$ treatments, whereas, the control showed the least stomatal conductance $\left(0.03 \mathrm{~mol} \mathrm{H}_{2} \mathrm{O} \mathrm{m}^{-2} \mathrm{~s}^{-1}\right)$ (Table 2).

\section{COLOUR DEVELOPMENT, YIELD AND K ${ }^{+}$CONTENT}

In all the three years, the fruit colour development was significantly enhanced by the 2,4-D treatments (Figure 2 ). During 1 st year study, we observed that at 28th days after anthesis, the $10 \mathrm{mg} \mathrm{L}^{-1}$-treated fruits showed $65 \%$ peel area covered by red color, whilst only $35 \%$ peel area of control fruits covered with red colour (Figure 2). Likewise, in 2nd and 3rd year, 2,4-D treatments also produced positive effects on peel colour development. With regard to fruit yield, 2,4-D treated branches produced higher yield compared with control. During the 1st year, $5 \mathrm{mg} \mathrm{L}^{-1}$ treatment produced 1.45-fold higher yield than the control (Table 2). For the 2nd and 3rd year, fruit yield were also significantly higher in treated branches compared with untreated branches (Table 3 ). In addition, $\mathrm{k}^{+}$content of wax apple fruit juice were significantly affected by 2,4-D treatments (Table 3).

\section{FRUIT MATURITY}

From the results, it can be seen that 2,4-D treatments significantly shortened the time it took for wax apple fruit to reach legal maturity (Figure 3). During the first year, all the treated fruits were harvested 6 to 9 day earlier than the control fruits. In 2nd year 2,4-D treatments also advanced fruit maturity or ripening by 5 to 8 day. Similar effects were observed in 3rd year (Figure 3 ).

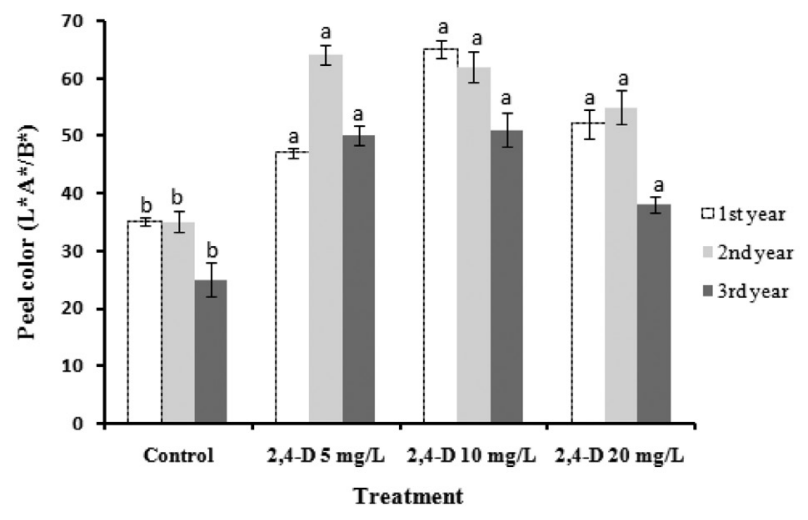

FIGURE 2. Effects of 2,4-D treatments on peel color development at 28th day after fruit set of wax apple under field condition. Means within the same column followed by the same letter, do not differ significantly according to LSD test at a $p \leq 0.05$. Bars indicate $( \pm$ S.E.)

TABLE 2. Effects of different treatments of 2,4-D on chlorophyll fluorescence, stomatal conductance and yield of wax apple

\begin{tabular}{|c|c|c|c|c|c|c|}
\hline \multirow{2}{*}{$\begin{array}{l}\text { Treatment } \\
\left(\mathrm{mg} \mathrm{L}^{-1}\right)\end{array}$} & \multicolumn{3}{|c|}{ Chlorophyll fluorescence } & \multirow{2}{*}{$\begin{array}{c}\text { Quantum } \\
\text { yield }\end{array}$} & \multirow{2}{*}{$\begin{array}{l}\text { Stomatal } \\
\text { cond. }\end{array}$} & \multirow{2}{*}{$\begin{array}{c}\text { Yield }(\mathrm{Kg}) \\
1 \text { st year }\end{array}$} \\
\hline & F0 & $\mathrm{Fm}$ & $\mathrm{Fv}$ & & & \\
\hline Control & $419 \pm 52 b$ & $1452 \pm 184 c$ & $1033 \pm 177 \mathrm{c}$ & $0.74 \pm 0.02 b$ & $0.03 \pm 0.004 b$ & $0.31 \pm 0.01 \mathrm{c}$ \\
\hline 2,4-D 5 & $641 \pm 69 a$ & $3005 \pm 221 \mathrm{a}$ & $2578 \pm 180 \mathrm{a}$ & $0.83 \pm 0.01 \mathrm{a}$ & $0.04 \pm 0.001 \mathrm{a}$ & $0.45 \pm 0.03 a$ \\
\hline 2,4-D 10 & $526 \pm 43 a$ & $2514 \pm 171 \mathrm{a}$ & $2055 \pm 135 a$ & $0.82 \pm 0.01 \mathrm{a}$ & $0.04 \pm 0.003 \mathrm{a}$ & $0.43 \pm 0.04 a$ \\
\hline 2,4-D 20 & $514 \pm 45 \mathrm{a}$ & $2093 \pm 218 b$ & $1479 \pm 144 b$ & $0.73 \pm 0.02 b$ & $0.04 \pm 0.002 \mathrm{a}$ & $0.36 \pm 0.02 b$ \\
\hline
\end{tabular}

Values in a column sharing the same lower case letters are not significantly different at $p \leq 0.05$ (LSD test) 
TABLE 3. Effects of different treatments of 2,4-D on yield, $\mathrm{K}^{+}$and total sugar content of, wax apple

\begin{tabular}{|c|c|c|c|c|c|c|}
\hline \multirow{2}{*}{$\begin{array}{l}\text { Treatment } \\
\left(\mathrm{mg} \mathrm{L}^{-1}\right)\end{array}$} & \multicolumn{2}{|c|}{ Yield (kg/treatment) } & \multirow{2}{*}{$\begin{array}{c}\mathrm{K}^{+} \\
\text {Content }\end{array}$} & \multicolumn{3}{|c|}{ Total sugar (g/100 g pulp) } \\
\hline & 2nd $Y$ & $3 r d Y$ & & 1st year & 2nd year & 3rd year \\
\hline Control & $0.35 \pm 0.02 \mathrm{c}$ & $0.32 \pm 0.02 c$ & $16 \pm 2.8 b$ & $2.54 \pm 0.27 b$ & $3.32 \pm 0.71 b$ & $3.95 \pm 0.47 \mathrm{~b}$ \\
\hline 2,4-D 5 & $0.47 \pm 0.06 \mathrm{a}$ & $0.44 \pm 0.05 a$ & $29 \pm 4.5 \mathrm{a}$ & $5.15 \pm 0.57 \mathrm{a}$ & $5.83 \pm 0.30 \mathrm{a}$ & $5.85 \pm 0.46 \mathrm{a}$ \\
\hline 2,4-D 10 & $0.52 \pm 0.05 a$ & $0.50 \pm 0.05 a$ & $44 \pm 4.2 \mathrm{a}$ & $5.20 \pm 0.25 a$ & $5.86 \pm 0.32 a$ & $5.90 \pm 0.26 \mathrm{a}$ \\
\hline 2,4-D 20 & $0.40 \pm 0.07 \mathrm{~b}$ & $0.41 \pm 0.08 b$ & $30 \pm 4.8 \mathrm{a}$ & $5.49 \pm 0.43 a$ & $5.81 \pm 0.27 \mathrm{a}$ & $5.62 \pm 0.34 \mathrm{a}$ \\
\hline
\end{tabular}

Values in a column sharing the same lower case letters are not significantly different at $p \leq 0.05$ (LSD test)

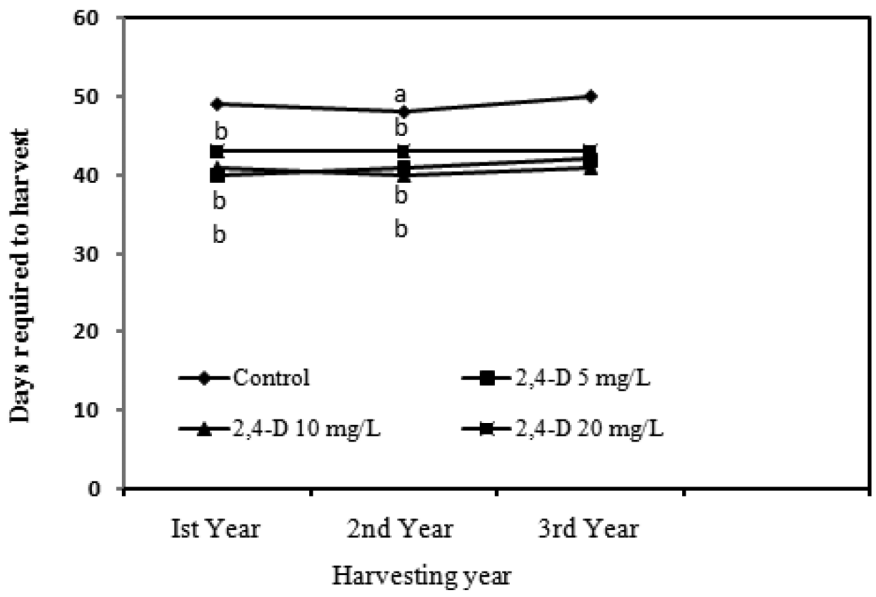

FIGURE 3. Effects of 2,4-D treatments on harvesting time of wax apple fruits under field conditions. Means within the same column of different line followed by the same letter, do not differ significantly according to LSD test at a $p \leq 0.05$

\section{TOTAL SOLUBLE SUGAR AND PROTEIN CONTENT}

The results from all the three years showed that total sugar content of wax apple fruit differed significantly between the treatments and control (Table 3). In the first year, the total sugar content was $104 \%$ higher in $10 \mathrm{mg} \mathrm{L}^{-1}$ treated wax apple fruits compared with control. As shown in Table 4 fruit protein of wax apple also increased significantly with 2,4-D treatments. The highest amount of protein (6.1 $\left.\mathrm{mg} \mathrm{g}^{-1}\right)$ was recorded in $5 \mathrm{mg} \mathrm{L}^{-1}$ - treated fruits, while the lowest amount of protein $\left(5.13 \mathrm{mg} \mathrm{g}^{-1}\right)$ was found in control fruits (Table 4). CHS activity differs significantly between the treated and untreated fruits. During the first 1st year, the CHS activity was 1.38 -fold higher in the fruits of $5 \mathrm{mg} \mathrm{L}^{-1}$ treatment compared with control. Consequently, in the last two years, the level of CHS activity elevated significantly by 2,4-D treatments (Table 4 ).
It can be seen that peel colour development was strongly correlated $\left(\mathrm{R}^{2}=0.98\right)$ with chalcone synthase activity treated fruits (Figure 6(b)).

\section{NET PHOTOSYNTHETIC RATE, LEAF SOLUBLE PROTEIN AND SPS ACTIVITY}

The results of 3rd year study showed that 2,4-D treatments produced significant effects on photosynthesis of treated wax apple plants (Figure 4). For $350 \mathrm{ppm} \mathrm{CO}_{2}$, the activities were 1.02-, 1.05- and 1.16-fold higher in $5 \mathrm{mg} \mathrm{L}^{-1}$ treatment than the control at 400,800 and $2000 \mu \mathrm{mol} \mathrm{m}^{-2} \mathrm{~s}^{-1}$ light intensity (Figure 4). Higher doses of 2,4-D produced negative effects on photosynthesis of treated plants. Protein content in treated leaves was significantly affected by $2,4-\mathrm{D}$ treatments (Figure 5(a).

TABLE 4. Effects of different treatments of 2,4-D on fruit protein and CHS enzyme activity of wax apple fruit

\begin{tabular}{ccccc}
\hline \multirow{2}{*}{$\begin{array}{c}\text { Treatment } \\
\left(\mathrm{mg} \mathrm{L}^{-1}\right)\end{array}$} & $\begin{array}{c}\text { Fruit protein } \\
\left(\mathrm{mg} \mathrm{g}^{-1} \text { pulp }\right)\end{array}$ & \multicolumn{3}{c}{ CHS enzyme activity (p mol g ${ }^{-1}$ protein) } \\
\cline { 3 - 5 } & & 1st year & 2nd year & 3rd year \\
\hline Control & $5.13 \pm 0.35 \mathrm{~b}$ & $4.2 \pm 0.40 \mathrm{~b}$ & $4.0 \pm 0.35 \mathrm{~b}$ & $4.3 \pm 0.39 \mathrm{~b}$ \\
2,4-D 5 & $6.1 \pm 0.38 \mathrm{a}$ & $5.8 \pm 0.31 \mathrm{a}$ & $5.3 \pm 0.50 \mathrm{a}$ & $6.0 \pm 0.46 \mathrm{a}$ \\
2,4-D 10 & $6.0 \pm 0.54 \mathrm{a}$ & $5.3 \pm 0.30 \mathrm{a}$ & $5.7 \pm 0.55 \mathrm{a}$ & $5.8 \pm 0.51 \mathrm{a}$ \\
2,4-D 20 & $5.8 \pm 0.45 \mathrm{a}$ & $5.6 \pm 0.52 \mathrm{a}$ & $5.3 \pm 0.47 \mathrm{a}$ & $5.4 \pm 0.42 \mathrm{a}$ \\
\hline
\end{tabular}

Values in a column sharing the same lower case letters are not significantly different at $p \leq 0.05$ (LSD test) 


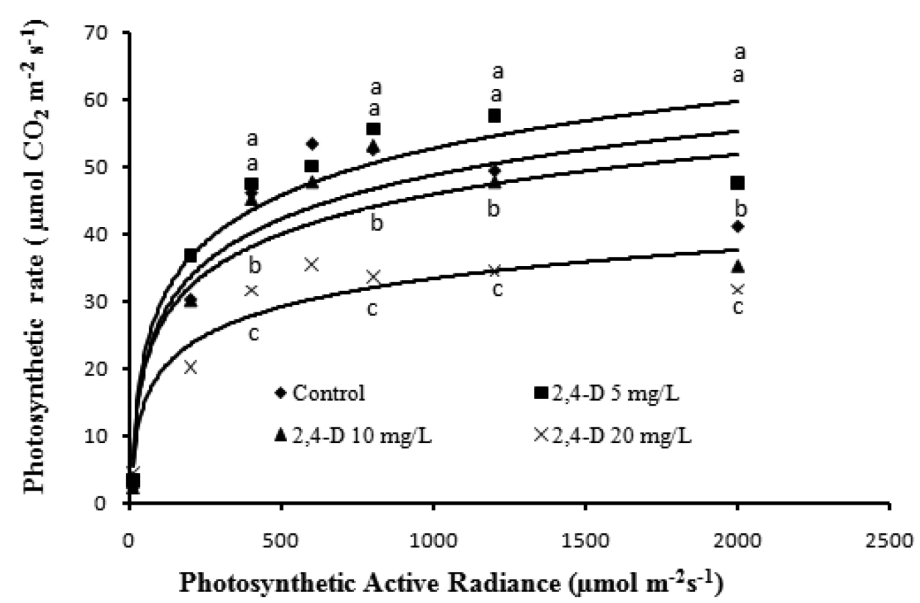

FIGURE 4. Effects of 2,4-D treatments on net photosynthetic rate of wax apple trees under field condition $(n=12)$. Data were recorded at 2 weeks after fruit set. Means within the same column of different line followed by the same letter, do not differ significantly according to LSD test at $p \leq 0.05$
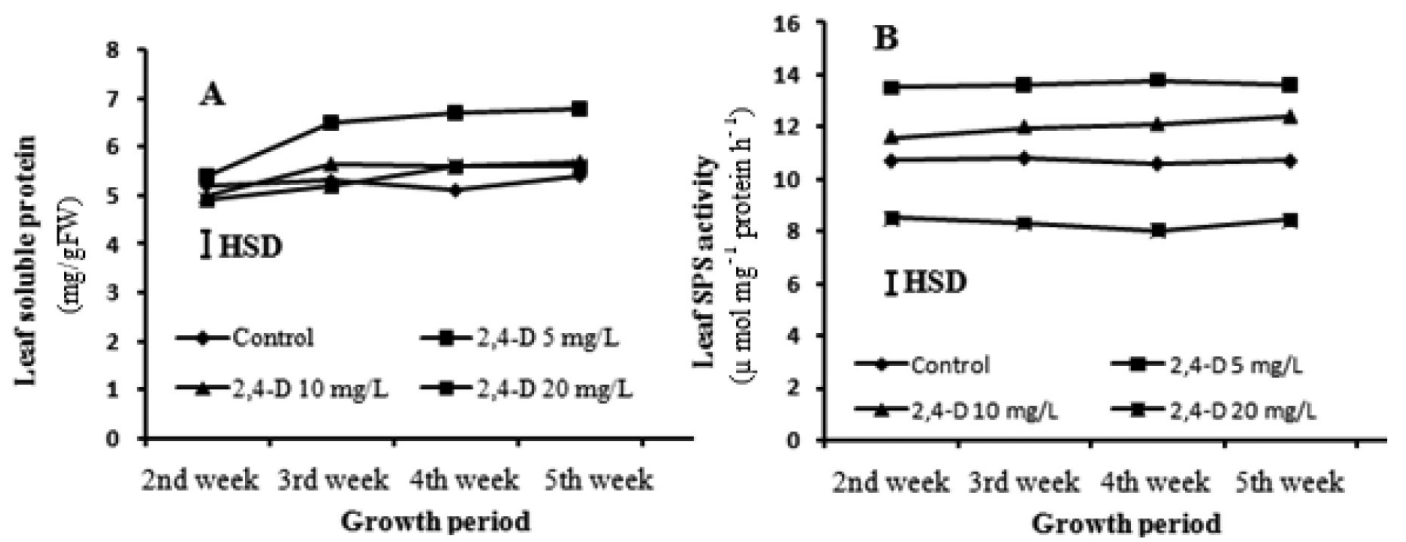

FIGURE 5. Effects of 2,4-D treatments on leaf soluble protein (a) and SPS activity (b) of wax apple trees under field condition at 3 rd week of observation $(n=3)$. Vertical bars indicate HSD value at $5 \%$ level of significance

The highest leaf soluble protein was recorded in $5 \mathrm{mg}$ $\mathrm{L}^{-1}$ treated branches, whereas, control and other treatments had lower protein contents. The sucrose phosphate synthase activity (SPS) was also significantly affected by $2,4-\mathrm{D}$ application throughout the fruit development (Figure 5(b)). At the 3rd week of observation, the highest SPS activity $\left(13.6 \mu \mathrm{mol} \mathrm{mg}^{-1}\right.$ protein $\left.\mathrm{h}^{-1}\right)$ was recorded in $5 \mathrm{mg} \mathrm{L}^{-1} 2,4-$ D treatment followed by $10 \mathrm{mg} / \mathrm{L}$ treatment and control, respectively, with a parallel enzyme activities of 12.0 and $10.8 \mu \mathrm{mol} \mathrm{mg}^{-1}$ protein $\mathrm{h}^{-1}$.

The lowest SPS activity $\left(8 \mu \mathrm{mol} \mathrm{mg}^{-1}\right.$ protein $\left.\mathrm{h}^{-1}\right)$ observed in $20 \mathrm{mg} \mathrm{L}^{-1}$ treatment (Figure 5(b)). Our results also showed positive correlation $\left(\mathrm{R}^{2}=0.96\right)$ between the net photosynthesis rate and sucrose phosphate activity in $5 \mathrm{mg} / \mathrm{L}$ treated plants (Figure 6(a)).

\section{DISCUSSION}

2,4-Dichlorophenoxy acetic acid has been used as a herbicide, in a higher doses, for the control of weeds in horticulture and agronomy (Montgomery 1993). However at low doses, the growth regulator has been documented to have a stimulatory effect on plant and cell growth (Joseph 2011). Growth regulators such as auxins (NAA and 2,4-D) have been shown to regulate bud development, fruit set and other physiological processes in plants (Maaike et al. 2009). In the present study, we did not observe any positive effects of 2,4-D on flower bud development. However, the results with regard to fruit set were found to concur with the findings of Lo'pez-Galarza et al. (2004), who reported that 2,4-D treatments increased fruit set in triploid watermelon. Growth regulators have been shown to possess a great influence on fruit drop and fruit retention in fruit trees. Our result showed that 2,4-D treatments significantly reduced bud and fruit drop, but at $20 \mathrm{mg} \mathrm{L}^{-1}$ it increased flower bud abscission. These results are in agreement with the findings of Davies and Zalman (2006) who observed that $2,4-\mathrm{D}$ increased fruit retention in citrus species. Chen et al. (2006) reported that an imbalance of auxins, cytokinins and gibberellins may lead to the formation of an abscission layer at the stem point which eventually causes fruit drop. The presence of auxins stop fruit drop by maintaining the 

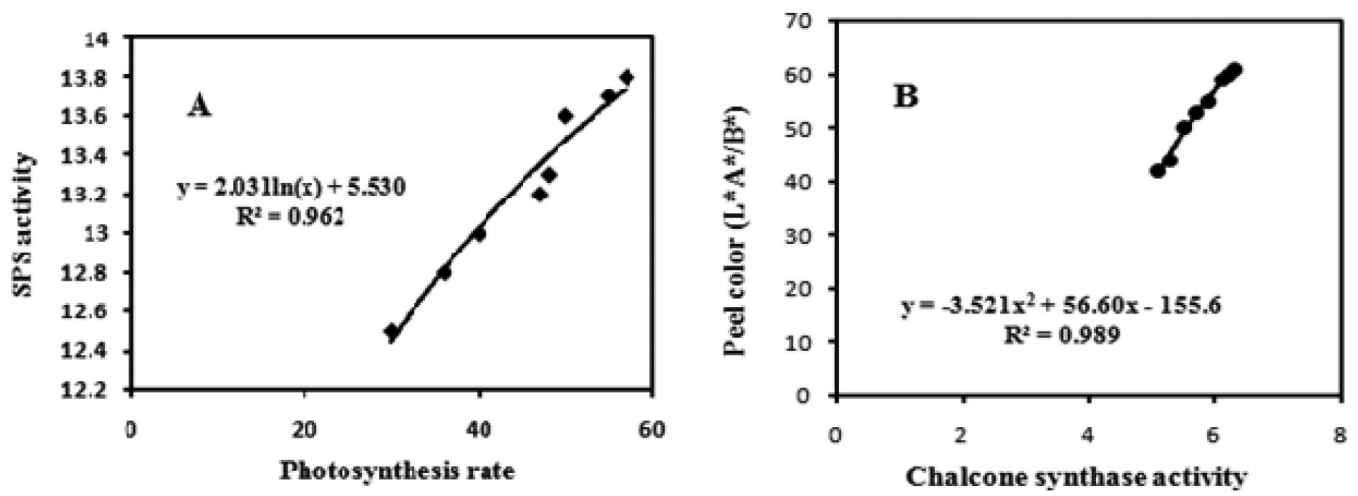

FIGURE 6 . The effects of $5 \mathrm{mg} \mathrm{L}^{-1} 2,4-\mathrm{D}$ treatments on correlation between photosynthetic activity and SPS activity (a) of leaves and between CHS activity and peel color (b) development of fruits of wax apple

cells at the zone of abscission, preventing the synthesis of hydrolytic enzymes such as cellulase, which decomposes the cell wall.

Auxin affects fruit growth during cell division and the cell enlargement phase. During the cell enlargement period, synthetic auxin increases photosynthesis and carbohydrate availability causing cell enlargement and also increase in final fruit size (Agusti et al. 1994). In this study, 2,4-D treatments stimulated fruit growth in wax apple through the fruit development stage and fruit growth was significantly different from the control. Similar findings was reported by Raphael et al. (2007) who found that exogenous application of synthetic auxin raised the carbohydrate level in the fruit and increased fruit size and weight in Bing cherry. Modise et al. (2008) reported that 2,4-D treatment significantly increased the average weight by enlarging fruit size in naval orange. Similar positive effects of 2,4-D on fruit weight were also observed in this study.

Leaf chlorophyll content is one of the most important factors that affects plant productivity as it can influence photosynthesis. In this study, 2,4-D treatments stimulated leaf chlorophyll content determined using the SPAD meter. Gutam et al. (2009) also reported that foliar spray of synthetic auxin increased the chlorophyll content in bell pepper. They also observed the greener leaves could be correlated to the possible increase in sugars resulting from the 2,4-D treatments. Our results also showed that 2,4-D treatments significantly increased the leaf dry matter (DM) in wax apple. Leaf photosynthetic efficiency $\left(\mathrm{F}_{\mathrm{v}} / \mathrm{F}_{\mathrm{m}}\right)$ was also affected positively by $2,4-\mathrm{D}$ treatments. Similar positive effects of growth regulators on leaf photosynthetic efficiency were reported by Zhang et al. (2003). The opening and closing of stomata, which will affect photosynthetic $\mathrm{CO}_{2}$ fixation in mesophyll tissues, has also been shown to be affected by synthetic auxin (figaron), where increased stomatal conductance at a low concentrations was observed in soybean (Nahar \& Takeshi 2002). In this study, leaf stomatal conductance was also affected by 2,4-D treatments.

Previous studies have reported that 2,4-D treatments increased fruit yield at a lower concentration $\left(20 \mathrm{mg} \mathrm{L}^{-1}\right)$, but at a higher concentration (30 and $\left.40 \mathrm{mg} \mathrm{L}^{-1}\right)$ it reduced fruit yield by increasing the premature drop (Modise et al. 2008). In the case of wax apple, 2,4-D also had a significant effect on fruit yield, whereby 2,4-D treatments significantly shortened the harvesting time and promoted ripening. Vendrell (2006) also reported similar results, whereby dipping in 2,4-D advanced ripening of tomato fruits by regulating respiration and ethylene production. Soluble sugars such as glucose and sucrose play a central role in metabolism and regulate many developmental and physiological processes in plants (Yu 1999). The results for the amount of total sugars in this study were in an agreement with those of Baogang et al. (2008) who observed that treatments of 2,4-D increased the total sugars contents in mango fruits. It was observed that the 2,4-D treatments had a positive effect on the potassium content of fruit juice. In this study the peel colour of wax apple fruit was significantly increased by 2,4-D application and which may be the result of an increased accumulation of pigments in the rind. However Shahbake et al. (1998) reported that the application of $250 \mu \mathrm{g} \mathrm{mL}-1$ 2,4-D (amine form) under storage conditions, greatly retarded the development of peel color in 'Valencia' oranges, contrary to our findings which showed the stimulatory effects of $2,4-\mathrm{D}$ on peel colour development.

Net photosynthetic rate in wax apple leaves increased notably with lower doses of 2,4-D. Similarly, Wong (2000) also reported that 2,4-D application increased net photosynthetic rate and chlorophyll synthesis in fresh water green algae. Our results also showed that net photosynthesis in wax apple leaves started to decrease when more than $10 \mathrm{mg} \mathrm{L}^{-1} 2,4-\mathrm{D}$ was used. This might be due to the reduction of $\mathrm{CO}_{2}$ fixation in leaf mesophyll tissues induced by stomatal closure.

It was also reported in our previous study that synthetic auxin promoted the biosynthesis of anthocyanin and carotenoids and increased the phenylalanine ammonia lyase (PAL) activity of fruits (Khandaker et al. 2012a). In the present study, 2,4-D treatments elevated the activity of chalcone synthase (CHS), an enzyme responsible for the synthesis of flavonoids and other pigments. This 
increase in CHS activity possibly stimulated the color development of wax apple fruits. Our results suggested that peel colour development strongly correlated with chalcone synthase activity in treated fruits. Leaf and fruit soluble protein content of treated plants increased with 2,4-D application. Osborne and Hallaway (1964) also reported that the application of 2,4-D in detached leaves of Prunus stimulated the synthesis of protein. Sucrose phosphate synthase, an enzyme important for the synthesis of sucrose in leaves was also affected by the 2,4$\mathrm{D}$ treatment. The results showed that net photosynthetic rate and sucrose phosphate synthase activity of treated plants increased with 2,4-D. The increased photosynthetic rate could possibly provided more fructose and glucose 6-phosphate which in turn stimulated sucrose synthesis via sucrose phosphate synthase activity. A strong correlation was observed between photosynthetic rate and sucrose phosphate synthase activity in treated plants.

Our three-year study have shown that 2,4-D treatments significantly affected several photosynthetic characteristics, sucrose phosphate synthase activity, fruit growth, yield and quality under field conditions, which makes it a viable option for use in horticulture, as it has been shown and documented that 2,4-D can be completely dissipated within 20 days of application (Voos \& Groffman 1997). In the present study, 2,4-D application was stopped one month before harvesting. Small amounts of 2,4-D (0$0.3 \mathrm{mg} \mathrm{kg}^{-1}$ ) is regarded as safe for human consumption (FAO/WHO 1972). Moore (1989) reported that a dosage of $15 \mathrm{mg} \mathrm{kg}^{-1}$ 2,4-D was found to be non-toxic in humans. It is assumed that there are very little amounts of 2,4-D residues in the treated fruits at the harvesting period. However further work would need to be done to allay fears amongst consumers that the amounts of 2,4-D residue in treated fruits are negligible or similar to endogenous levels at harvesting time.

\section{CONCLUSION}

The results showed that application of 2,4-D at concentrations of 5 and $10 \mathrm{mg} / \mathrm{L}$ can improve the plant physiological properties, productivity and quality of wax apple fruits under field conditions. Application of 2,4-D at concentrations of 5 and $10 \mathrm{mg} \mathrm{L}^{-1}$ elevated net photosynthetic rate, chlorophyll content, stomatal conductance and chlorophyll fluorescence. On the contrary, 2,4-D at a concentration of $5 \mathrm{mg} \mathrm{L}^{-1}$ can improve fruit set, reduced bud and fruit drop, enhanced fruit growth and fruit weight and leaf dry matter. Additionally, application of 2,4-D at concentrations of 5 and $10 \mathrm{mg} \mathrm{L}^{-1}$ gave promising results with respect of fruit set, fruit growth, colour development, earlier maturity and fruit yield. Furthermore, $\mathrm{K}^{+}$, sugar and protein content, chalcone synthase and sucrose phosphate synthase activities were also increased significantly. Our results also showed that 2,4-D treated leaves and fruits of wax apple showed positive correlations between net photosynthetic rate and SPS activity and between CHS activity and peel colour development of fruits.
Our findings suggested that 2,4-D at concentrations of 5 and $10 \mathrm{mg} \mathrm{L}^{-1}$ are promising concentrations for enhancing the fruit growth, yield and improving the quality of wax apple under field conditions.

\section{ACKNOWLEDGEMENTS}

We greatly thank University of Malaya (Project No. RG002/09BIO) and University of Sultan Zainal Abidin (Project No.UniSZA/14/GU/024) for the financial support and publication.

\section{REFERENCES}

Agusti, M., Almela, V., Aznar, M., El-Otmani, M. \& Pons, J. 1994. Satsuma mandarin fruit size increased by 2,4-DP. Hort Science 29: 279-281.

Ashraf, M.Y., Ashraf, M., Akhtar, M., Mahmood, K. \& Saleem, M. 2013. Improvement in yield, quality and reduction in fruit drop in Kinnow (Citrus reticulate Blanco) by Exogenous application of plant growth regulators, potassium and zinc. Pakistan Journal of Botany 45: 433-440.

Baogang, W., Jianhui, W., Hao, L., Jianyong, Y., Jingjing, Z., Lin, L., Yu, W., Xiaoyuan, F., Jiankang, C. \& Weibo, J. 2008. Reduced chilling injury in mango fruit by 2,4-dichlorophenoxyacetic acid and the antioxidant response. Postharvest Biology and Technology 48: 172-181.

Bradford, M.M. 1976. A rapid and sensitive method for the quantitation of microgram quantities of protein utilizing the principle of protein dye binding. Anal Biochemistry 72: 248-254.

Chen, H., Dekkers, K.L., Cao, L., Burns, J.K., Timmer, L.W. \& Chung, K. 2006. Evaluation of growth regulator inhibitors for controlling post bloom fruit drop (PFD) of citrus induced by fungi in Colletotrichum acutatum. Hort Science 4: 317-321.

Davies, F.S. \& Zalman, G. 2006. Gibberellic acid, fruit freezing, and post-freeze quality of Hamlin oranges. Hort Technology 16: 301-305.

Dubois, M.K., Gils, J.K., Hanniton, P.A., Robes \& Smith, F. 1956. Use of phenol reagent for the determination of total sugar. Anal Chemistry 28: 350-356.

Edwards, R., Kessmann, H. \& Bowles, D.J. 1990. Molecular Plant Pathology: A Practical Approach. Oxford: IRL Press.

FAO/WHO 1972. 1971. Evaluations of Some Pesticide Residues in Food. AGP/1971/M/9/1; WHO Pesticide Residues Series, No. 1.

Gutam, S., Koti, R.V., Chetti, M.B.\& Hiremath, S.M. 2009.Effect of NAA and Mepiquat chloride on physiological components of yield. African Journal of Agricultural Research 47: 210 216.

Hubbard, N.L., Huber, S.C. \& Pharr, D.M. 1989. Sucrose phosphate synthase and acid invertase as determinants of sucrose concentration in developing muskmelon (Cucumis melo L.) fruit. Plant Physiology 91: 1527-1534.

Ismail, B.S., Kader, A.F. \& Omar, O. 1995. Effects of glyphosphate on cellulose decomposition in two soils. Folia Microbiology 40: 499-502.

Janick, J. \& Paul, R.E. 2008. The Encyclopedia of Fruits and Nuts. Wallingford, Oxfordshire: CABI. p. 551.

Joseph, M.D. 2011. Mode of action of the growth regulator herbicides. Davis, CA: University of California (Unpublished)

Kataoka, K., Yashiro, Y., Habu, T., Sunamoto, K. \& Kitajima, A. 2009. The addition of gibberellic acid to auxin solutions increases sugar accumulation and sink strength in developing 
auxin-induced parthenocarpic tomato fruits. Scientia Horticulturae 123: 228-233.

Khandaker, M.M., Hossain, A.B.M.S., Osman, N.\& Boyce,A.N. 2011. Application of girdling for improved fruit retention, yield and fruit quality in Syzygium samarangense under field conditions. International Journal of Agriculture and Biology 13: 18-24.

Khandaker, M.M., Boyce, A.N., Osman, N. \& Hossain, A.B.M.S. 2012a. Physiochemical and phytochemical properties of wax apple (Syzygium samarangense [Blume] Merrill \& L.M.Perry var. jambu madu) as affected by growth regulator application. Scientific World Journal 2012: 1-13.

Khandaker, M.M., Boyce, A.N. \& Osman, N. 2012b. The influence of hydrogen peroxide on the growth, development and quality of wax apple (Syzygium samarangense, [Blume] Merrill \& L.M. Perry var. jambu madu) fruits. Plant Physiology \& Biochemistry 53: 101-110.

Lo'pez-Galarza, S., San Bautista, A., Perez, M., Miguel, A., Baixauli, C., Pascual, B., Maroto, J.V. \& Guardiola, J.L. 2004. Effects of grafting and cytokinin-induced fruit setting on color and sugar-content traits in glasshouse-grown triploid watermelon. Journal of Horticultural Science and Biotechnology 79: 971-976.

Maaike, D.J., Celestina, M., Wim, H. \& Vriezen. 2009. The role of auxin and gibberellin in tomato fruit set. Journal of Experimental Botany 60: 1523-1532.

Ma, Q., Ding, Y., Chang, J., Sun, X., Zhang, L., Wei, Q., Cheng, Y., Chen, L., Xu, J. \& Deng, X. 2014. Comprehensive insights on how 2,4-dichlorophenoxyacetic acid retards senescence in post-harvest citrus fruits using transcriptomic and proteomic approaches. Journal of Experimental Botany 65: 61-74.

Modise, D.M., Likuku, A.S., Thuma, M. \& Phuti, R. 2008. The influence of exogenously applied 2,4-dichlorophenoxyacetic acid on fruit drop and quality of navel oranges (Citrus sinensis L.) African Journal of Biotechnology 8: 2131-2137.

Morton, J.F. 1987. Fruits of Warm Climates. Miami, Florida. pp. 381-382.

Montgomery, J.H. 1993. Agrochemicals Desk Reference. Boca Raton: Lewis Publishers, c1993, Australia.

Moore, T. 1989. Biochemistry and Physiology of Plant Hormones. 2nd ed. New York: Springer-Verlag.

Nahar, B.S.\& Takeshi, I. 2002. Effect of different concentrations of figaron on production and abscission of reproductive organs, growth and yield in soybean (Glycine max L.). Field Crop Research 78: 41-50.

Osborne, D.J. \& Hallaway, M. 1964. The auxin 2,4-Dichlorophenoxy acetic acid, as regulator of protein synthesis and senescence in detached leaves of Prunus. New Phytologist 63(3): 334-347.

Raphael, A.S., Moshe, F., Steve, A. \& Ruth, B.A. 2007. Effect of synthetic auxins on fruit development of 'Bing' cherry (Prunus avium L.). Scientia Horticulturae 114: 275-280.

Rivera, D. \& Obón, C. 1995. The ethnopharmacology of Madeira and Porto Santo Islands, a review. Journal of Ethnopharmacology 46: 73-93.

Shahbake, M., McGlasson, B., Brown, M.A., Wild, B.L. \& Patterson, B.D. 1998. Effects of growth substances, ethylene inhibitors and heat disinfestations treatments on citrus fruit stem end rot. Acta Horticulturae (ISHS) 464: 522-522.
Sterling, T.M. \& Hall, J.C. 1997. Mechanism of action of natural auxins and the auxinic herbicides. In Herbicide Activity: Toxicology, Biochemistry and Molecular Biology, edited by Roe, R.M., Burton, J.D. \& Kuhr, R.J. Amsterdam, Netherlands: IOS. pp. 111-142.

Tuan, M., Nguyen \& Yen, C.R. 2013. Response of wax apple cultivars by applied GA3 and 2,4-D on fruit growth and fruit quality. International Journal of Biological, Food, Veterinary and Agricultural Engineering 7: 28-36.

Vendrell, M. 2006. Dual effect of 2,4-D on ethylene production and ripening of tomato fruit tissue. Physiology Plantarum 64: 559-563.

Voos, G. \& Groffman, P.M. 1997. Dissipation of 2,4-D and dicamba in a heterogeneous landscape. Applied Soil and Ecology 5: 181-187.

Wong, P.K. 2000. Effects of 2,4-D, glyphosate and paraquat on growth, photosynthesis and chlorophylla synthesis of Scenedesmus musquadricauda Berb 614. Chemosphere 41: 177-182.

Yu, S.M. 1999. Cellular and genetic responses of plants to sugar starvation. Plant Physiology 121: 687- 693.

Zen-Hong, S., Meon, Z., Tirtawinata, R. \& Thanarut, C. 2006. Wax apple production in selected tropical Asian countries. ISHS Acta Hort 773: 161-164.

Zhang, X.Z., Ervin, E.H. \& Schmidt, R.E. 2003. Plant growth regulators can enhance the recovery of kentucky bluegrass sod from heat injury. Crop Science 43: 952-956.

Mohammad Moneruzzaman Khandaker*

School of Agriculture Science and Biotechnology

Faculty of Bioresources and Food Industry

Universiti Sultan Zainal Abidin

Tembila Campus, 22200 Besut, Terengganu

Malaysia

Normaniza Osman, Golam Faruq \& Amru Nasrulhaq Boyce

Institute of Biological Sciences

Faculty of Science, University of Malaya

50603 Kuala Lumpur

Malaysia

ABM Sharif Hossain

Biotechnology Program, Biological Sciences

Faculty of Science, University of Hail, Hail

KSA

*Corresponding author, email: moneruzzaman@unisza.edu.my

Received: 18 December 2013

Accepted: 16 June 2015 